\title{
REINVENTING CULTURAL IDENTITIES IN DIASPORA: A MOTHER-DAUGHTER DYAD IN TAN'S NARRATIVES
}

\author{
Nagendra Bahadur Bhandari*
}

\begin{abstract}
Immigrants suffer problematic cultural identities due to their bicultural allegiances to their host and native cultures. They can not be totally free from their 'being', the shared cultural and historical experiences. As a result, they follow their cultural practices of native country even in their diasporic existences. At the same time, they adopt and follow the cultural practices of the host country. In fact, they are living in the cultural third space simultaneously oscillating between two cultures. In such cultural in-betweenness, the first generation and the second generation immigrants undergo different experience in diaspora. In this article, Chinese American writer Amy Tan's two fictions namely The Joy Luck Club and The Bonesetter's Daughter are analyzed focusing on cultural identities of second generation immigrants. The second generation in these narratives is the daughters of Chinese immigrant mothers. Their relationship with their mothers unfolds their simultaneous attraction and distraction to the both native and host culture. Consequently, their cultural identities remain unstable, blurred and in the processes of transformation in the cultural third space of diaspora.
\end{abstract}

Key words: Amy tan, becoming, being, cultural identity, diaspora, third space.

\section{INTRODUCTION AND OBJECTIVE}

Living in diaspora with multiple cultural allegiances renders crisis in cultural identities. Amid the conflicts of their native and host cultures, immigrants struggle to maintain their cultural identity. In fact, there is always a tension between desires to belong to the new society and an urge to retain the culture of the old one. Immigrants follow certain cultural practices of their native land even though they are living in foreign land. At the same time, they cannot resist the influences of the mainstream cultural practices of the host country. Willing or unwilling, they become part of acculturation process. Consequently, they oscillate between two cultures without forsaking the one. Exhibiting ambivalence to both cultures, they

* Mr. Bhandari is an Associated with Prithivi Narayan Campus, Pokhara, TU. 
occupy two cultural spaces at once. Consequently, the straddling between two cultural spaces of diaspora problematizes their cultural identity.

Hall (1994) explores the problematic of cultural identity in "Cultural Identity and Diaspora". His conceptualizations encompass two specific trends in cultural identity. The first is essentialist view of cultural identity. According to this view, the common ancestry and shared cultural values play decisive role in shaping our cultural identity. He elaborates:

The first position defines 'cultural identity' in term of one, shared culture, a sort of collective 'one true self', hiding inside the many other more 'selves', which people with a shared history and ancestry holds in common. Within the term of this definition, our cultural identities reflect the common historical experiences and shared cultural codes which provide us 'one people' with stable unchanging and continuous frame of reference and meaning, beneath the shifting divisions and vicissitudes of our actual histories....Such a conception of cultural identity played a critical role in all the post-colonial struggles which have so profoundly reshaped our world. (p. 223)

This essentialist view argues that there is an authentic cultural identity, a true self, which people with shared history and ancestry maintain ever after. This is understood as a stable, unchanging and continuous frame of reference and meaning that reflect the general shared cultural codes and common shared historical experience. This sense of cultural identity plays decisive role in anti colonial and other social struggle for right and justice. For Hall (1994), the essentialist view alone is not sufficient in conceptualizing cultural identity. Beside similarities, human beings embody marked differences which also contribute in defining who they are. Encompassing the differences and the process of forming cultural identity, Hall explicates:

It is not something which already exists, transcending place, time, history and culture. Cultural identities come from somewhere, have histories. But, like everything which is historical, they undergo constant transformation. Far from being eternally fixed on some essentalized past, they subject to the continuous 'play' of history, culture and power. (p. 225)

Identities are not externally fixed in some esssentialized past, but the continuous play of history, culture and power. In other words, cultural identity is part of both 'being' i.e. shared culture and common ancestry and 'becoming' i.e. the present struggle within certain power relationship. The power relationship of cultures affects the way in which these identities are positioned in the dominant regimes of representation. 
Taking references of colonial and postcolonial context, Bhabha (1994) makes perspective comments about cultural identity. Bhabha argues that culture does not exist in isolation. It interacts and negotiates with other cultures. Such a process of interaction and negotiation renders cultural transformation that shapes a cultural identity of a person. Such process is quite evident in the lives of immigrants in diaspora. Immigrants bring with them the residuals of native culture which get negotiated with cultural practices of host country. In fact, they are living somewhere in between these two cultures. The engagement in transcultural conversation between the host and the native cultures opens up avenues for transformation. Exploring the negotiation and transformation in transcultural space, Bhabha proposes the concept of the third space.

Bhabha's third space refers to cultural encounters in contradictory and ambivalent spaces. Cultural identities are negotiated and contested in this space. Bhabha sees the third space as the potential location and starting-point: It is that Third Space, though unrepresentable in itself, which constitutes the discursive conditions of enunciation that ensure that the meaning and symbols of culture have no primordial unity or fixity; that even the same signs can be appropriated, translated, rehistoricized and read anew. (p. 37) This third space makes meaning an ambivalent process not a fixed reference. Third space in itself is not representable; it is not an actual space; but it is caused by the openness of sign and symbols and culture that can be appropriated, translated, rehistoricized, and read anew. It is a space of hybridity in and between cultural differences. Cultural identity always emerges in this fluid, contradictory and ambivalent third space. There is no purity and hierarchy of cultures in this space.

To understand the liminality of third space, Bhabha (1994) uses the metaphor of a staircase. He cites an example of a house with several floors that are joined by a staircase. A house may consist of several floors that are accessible by a staircase. In order to move from the first to the second floor or vice versa, one needs to use the stairs. The staircase is, thus, metaphorically speaking transcending 'certain binary oppositions' such as high and low by offering a liminal space and a pathway between the extremes. Bhabha (1994) regards the liminal space of the staircase as an interstitial passage that allows a social subject to move in and out of different racial subject positions. Deleuze and Guattari's concept of rhizomatic cartography helps understand the third space theory. Rhizomes grow from multiple points in multiple directions simultaneously on a tree. Rhizomes constantly shift and change, growing simultaneously in all directions. Rather than a tree, with a central knowledge concept from which other knowledge branches off, 
rhizomes produce knowledge at multiple points and can jump to new points at any time. This rhizome metaphor matches with third space theory. It emphasizes that there are multiple points of power in any given interaction rather than a single power entity that controls everything. Moreover, the multiplicities of power centers open the possibility of multilateral directions of possible extensions.

Diaspora Literature explores the cultural identity of immigrants living in the third space. So the themes of; "alienation, loneliness, homesickness, existential rootlessness, nostalgia, questioning, protest, and assertions and the quest for identity" (Cordelia 1) are juxtaposed with issues of amalgamation of cultures and its influences on cultural identity of immigrants in literature dealing with diasporic existence. Following the suit, Chinese American writer Tan explores cultural identity of Chinese immigrants in her narratives. In her own life, she practices the cultural practices of both her Chinese parents and mainstream American society like a typical child of an immigrant parent. As a result, her narratives deal with lives of Chinese American particularly the dilemma and confusion about their cultural identity. She has published many narratives such as The Joy Luck Club (1989), The Kitchen God's Wife (1991), The Hundred Secret Senses (1995), The Bonesetter's Daughter (2001), The Opposite of Fate: A Book of Musing (2003), Saving Fish from Drowning (2005), and two children books; The Moon Lady (1992) and Sagwa, The Chinese Siamese Cat (1994).

Tan's two fictions namely The Joy Luck Club and The Bonesetter's Daughter are analyzed focusing on cultural identities of second generation immigrants in this article. The second generation in these narratives is the daughters of Chinese immigrants. So, the analysis of their relationship with their mothers shows their simultaneous attraction and distraction to the both native and host culture. For the daughters, Mothers embody Chinese culture and heritages. Their conflicts and confluences with their mothers display ambivalent attitude to the native Chinese and host American culture. Her first novel, The Joy Luck Club contains sixteen interrelated stories in four sections about conflicts between Chinese immigrant mothers and their American-raised daughters. The four pair mothers- daughters' stories are interwoven in the novel and resemble a complex process of constructing a Chinese diasporic identity. Similarly, The Bonesetter's Daughter spans over the lives of the three generations; the grandmother known as Precious Aunties, mother LuLing and her American born and brought up daughter Ruth. Mainly, mother LuLing and daughter Ruth conflict and confluence with constant reference to Precious Auntie exploring cultural identity in 
diasporic geo-cultural space. Both novels deal with intergenerational and intercultural conflicts of first generation immigrant mothers and their second generation immigrant daughters in diaspora.

The two generations of Chinese American characters living in the American Diaspora conflict and confluence, respectively. In pursuit of their higher education, prospective careers and better life style in the US, the first generation Chinese family in America persistently struggles to settle in the new setting while conserving their original indigenous cultures. Despite difficulties, the first generation immigrants in the US rigorously intend to perpetuate their original culture deeply rooted in their subconscious. However, they manifest different degrees of flexibility and adoptability to the American culture. In the same way, the second generation characters, the children of first generation immigrants, live in cultural hybrid space. In home, they are initiated with the culture of their origin; outside home, they are pertinently exposed to the America culture. Immigrants' aspiration of assimilating in the main stream American culture is recurrently questioned by their biological inheritance and social constructs. Chinese American immigrants, without totally forsaking one culture while following the other, tend to live with the shared cultures, partly western and partly eastern. In Tan's narratives both generations vacillate between past and present, the colonized eastern and colonial western, and the indigenous native Chinese and the new host American culture primarily because of their formal training in the mainstream American society in contrast from the upbringing in the family and domestic setting under their Chinese parents. In such circumstances, a pertinent question often recurs: why do these immigrant characters simultaneously travel through cultures of their origin and that of the host country? And what is the effect of such cultural interaction in the formation of Chinese Americans' identities represented in Tan's narratives?

\section{Critical Responses on Tan's Narratives}

The depictions of Chinese American lives get lots of readership and critical responses in Tan's narratives. Critics have analyzed issues of personal, familial, and cultural conflicts between American-born daughters and their Chinese mothers in Tan narratives. There is also debate among critics about whether the cross generational stories of Tan negotiates and bridges or manipulates and compromises Chinese disapora identities. In the same way, critics are also divided whether Tan has embraced orientalism for commercial success. Moreover, the role of memory, Chinese tradition 
of talk stories and presentation of female characters are other issues that have got critical attention in her works.

Chin (1974), Xu (2009) \& Lowe (1996) argue the presentation of Chinese cultural heritages and people in Tan's narratives. Fran Chin accuses her borrowing orientalist approach in depicting china whereas $\mathrm{Xu}$ and Lowe oppose such argument. Unlike them, Zeng (2008) does not enter into the debate. Zeng considers that exploitation of Chinese culture and heritage enables Tan to create counter culture in American literary tradition. Moreover, Iuliana Vizan raises the issue of female's revolt in Tan's narratives. On the other hand, Xu (2017) and Lotfi (2015) analyze memory, its interaction with history in shaping personal identity. Different dimensions of Chinese born mother and American born daughter draw critical appraisal of Chen Xiaomei, He Jing, Gulden Yuksel and E.D. Huntley. Unlike them, Dunick (2017), Yuan (2017) and Romagnolo (1994) analyze the limit, relevance and discursiveness of talk-story tradition. Hence the exploration of the intergenerational negotiation in relationship with formation of cultural identity of second generation immigrants in diasporic third space still retains relevance.

In this study Chinese American writer Tan's two fictions are analyzed focusing on immigrati's second generation cultural identifies.

\section{ANALYSIS}

Tan's The Bonesetter's Daughter spans over three generations, which include Precious Auntie or Gu Liu Xing (the grandmother), LuLing Liu Young (the mother) and Ruth (the daughter). Out of them Precious Auntie spends her entire life in her home country China. LuLing is first generation Chinese immigrants in America. Her daughter Ruth is second generation Chinese immigrants living in America. Ruth's father, Edwin Young, is an American. So, Ruth's mixed cultural heritages render uncertainties in her cultural affiliation. Both LuLing and Ruth experience the bicultural situation that renders lots of problems, dilemma and confusion in their lives.

Ruth experiences confusion and dilemma about her cultural identity throughout her childhood and adolescence as she can neither identify herself for sure as Chinese nor American. Although she is American by birth and desperately wants to lead an American life. At the same time, Ruth cannot completely deny her Chinese heritage. Her mother is a constant reminder of her ancestry. A native from China, her mother refuses to assimilate into the American culture and adamantly stands by the Chinese ways of thinking. She leads a very Chinese life and brings Ruth up according to 
the authoritarian Chinese parenting style. LuLing's attitude frustrates Ruth greatly as she is unable to relate optimistically to a Chinese environment. The clash of cultures generates many misunderstandings and this causes a rift in the relationship between mother and daughter.

Ruth shuns her Chineseness during her adolescence and commits herself wholeheartedly to being American. She has American friends, an American education and thus, an American mentality. Like other teenager, Ruth is filled with the huge need to fit in the crowd. At sixteen, she begins smoking which is normal among American teenagers. Most Chinese parents, however, would probably frown upon such behavior. When LuLing discovers that Ruth is smoking, she launches into an angry tirade. Ruth, then, shouts back, "I'm an American! I have a right to privacy ..." (Tan, p.158). This declaration indicates Ruth's deep desire to be recognized as an American. At fifteen, she also begins stealing money from her mother to buy "forbidden things like mascara, movie tickets or Marlboro cigarettes" (155). Thus, she adamantly does things that are deemed as "normal" by American teenagers. In the same way, Ruth lives with Art for several years without marrying him. Ruth passionately adopts American values and lifestyle.

Ruth often considers everything American is better than Chinese. She often thinks herself as deprived of an American life because of her mother's Chinese upbringing. Mother's restriction of having American fast food like chocolate milk, doughnuts and ice-cream sandwiches irritates her. Moreover, Ruth is horrified to discover that her mother is secretly reading her diary at sixteen. Filled with rage, she scribbles harsh words into her diary, knowing that her mother will read them; "You talk about killing yourself, so why don't you ever do it? Precious Auntie wants you to, and so do I!" (159). Ruth's American notion of privacy and independence collide with overprotective nature of her Chinese American mother. Moreover, she is irritated with her mother's beliefs on ghost and curses So; "She used to wish that her mother were more like Auntie Gal. She didn't talk about ghosts or bad luck or ways she might die" (52). Consequently, Ruth adopts American lifestyle projecting her mother as an embodiment of Chinese culture.

Despite Ruth's fascination to American lifestyle, she also follows Chinese cultural practices. For instances she invites her relatives and friends for the Full Moon Festival, a Chinese festival. However, her invitees and ordered food items reflect her both Chinese and American allegiances. There are many friends and relatives from both American and Chinese 
sides. Similarly, she orders both American and Chinese food for the dinner. Moreover, she does not want to make others uncomfortable due to her way of following Chinese culture. This makes her to be more conscious of her and also of her mother's behavior in public. She feels uncomfortable when her mother behaves in a Chinese way. Even though she follows certain practices from Chinese tradition, she depicts herself as an American.

Although Ruth does not like her mother ways of living and attitude, which is predominantly Chinese, Ruth integrates parts of her mother's behavior into her own character. For example, she shares LuLing's strong resolve to achieve her goals in life. When Ruth discovers that her mother's memory is being ravished by dementia, she is determined to learn about LuLing's past. She hires a translator to decipher her mother's memoir which is written in Mandarin. After reading the manuscript, Ruth is able to relate positively to her Chinese heritage and embraces it more willingly. It also bridges the gap between mother and daughter as understanding blossoms between both parties. At last she sees her mother in a new light. She wants to tell her, "I'm sorry and I forgive you too" (353). She becomes aware of her mother's heroism and hence, is less resistant to identifying with her mother and more receptive to her wisdom.

The knowledge about mother's past life rekindles Ruth's passion for her Chinese cultural heritages. This is reflected in her changing perspectives to her mother and appreciation of her sacrifice and struggle. She no longer views herself as a daughter of an embarrassing Chinese mother. She changes her perception and views herself as a daughter of a courageous and resilient mother. Ruth eventually admits that her grandmother and mother; "are the women who shaped her life,... . They caused her to question whether the order and disorder of her life were due to fate or luck, self-determination or the actions of others" (402). With such realization, she is able to see the beauty behind the meaning of Chinese traditions and words; "Ruth had once thought Chinese was limited in its sounds and thus confusing. It seemed to her now that its multiple meanings made it very rich" (398). After learning her mother's story, a new awareness emerges and it prompts Ruth to appreciate her own heritage. This return to the mother is also the return to the cultural roots.

Similarly, in The Joy Luck Club, the daughters Jing-Mei, Waverly, Rose and Lena are second generation Chinese immigrants who struggle in coping with the bicultural situation. They have American education, American friends, and American surroundings outside of their home. But they are exposed with Chinese culture at home. Their mothers try to 
implant Chinese traits and qualities on their daughters who have assimilated American lifestyle. Lindo Jong, a mother, succinctly puts it; "I wanted my children to have the best combination: American circumstances and Chinese Character. How could I know these two things do not mix?" (Tan, Joy Luck 199). As a typical Chinese mother Suyuan Woo expects her daughter Jing-Mei to be a prodigy and best, without considering of Jing-Mei as an individual but simply a Chinese daughter. Suyuan is only making all those efforts single-handedly without deep communication with Jing-Mei to understand her real interest or potential. Jing-Mei often fails the tests and thus disappoints her mother at times. The daughters are, thus, forced to live up to the expectation of Chinese mothers in American cultural milieu.

Chinese mothers behaves in overprotective manner to their American born daughters. Like Suyuan, Lindo Jong also seems to be possessive and dominating. Her daughter, Waverly is a national chess champion at the age of nine. Waverly is considered a prodigy. Her photo appears on the cover of the life magazine. Lindo proudly introduces her celebrity daughter to everybody. Lindo talks to people as if she devised all the strategies and tries to take all the credits for Waverly's victories. She polishes Waverly's trophies several times a day to satisfy her own sense of pride in being the mother of a prodigy. While Lindo sees Waverly's honor as her own just as a traditional Chinese mother regards her daughter as one of her possessions. In a sense, she discredits her daughter from her success unintentionally as the daughter remains invisible in the glorification of her own success.

Developing sense of individualism like an American girl, the daughters reject and resist their mothers' manner of upbringing. For instance, Jing- Mei confesses to her self-protective strategy against her mother; "I had new thoughts, willful thoughts, or rather thoughts filled with lots of won'ts. I won't let her change me, I promised myself. I won't be what I'm not" (118). Waverly also sees herself as a separate individual. Therefore, Waverly grows increasingly annoyed by her mother's behaviors, and she tells her mother to shut up, When her mother proudly walks with her daughter on the street and says to whoever looks her way; "This is my daughter Waverly Jong" (101). The conflict between mother and daughter reaches a boiling point with Waverly shouting at her mother; "Why do you have to use me to show off? If you want to show off, then why don't you learn to play chess?" (101). Thus, daughters begin to claim their individuality like an American girl by resisting their mothers' overprotective and authoritarian behavior.

The daughters hate the Chinesenss of their mothers. The Chinese biological traits and broken English of their mothers are the matter of shame 
for daughters. In their eyes, mothers' language is alienated from their fluent English and cannot be accepted. When Waverly is getting married for a second time, she asks her mother, Lindo, to go to her beauty Parlor. Lindo is acutely aware that Waverly does so because her daughter is ashamed for her mother and worries about what her American husband's parents will think of; "this backward old Chinese woman" (290). Waverly keeps telling the hairdresser; "She wants a soft wave. She doesn't want it to look kinky or weird" (291). She speaks for her mother and translates English for her mother as though Lindo does not understand English. Obviously, the American-born daughters harbor negative self-image about their Chinese ancestry which their mothers embody.

Despite the daughters attempt to Americanized themselves; they are subjected to the othering and racist behavior. American born daughters Rose "learned to choose for the best opinions. American people had American opinions. And in almost every case, the American version was much better" (214). However, the efforts they put in order to identity with White American culture can't determine the White people's attitude toward them. While attending a party at her white boyfriend's family, Rose experiences her boyfriend Ted's mother Mrs. Jordan's racist judgment. Mrs. Jordan does not like their relationship because of Rose Chinese ethnic background and Jordan remarks that Rose's ethnic background will degrade Ted's future career. Such racist treatments disillusion American born daughters' fascination of assimilating into American mainstream culture.

Later on, the American born daughters seems to be sympathetic to Chinese culture in their adult life. They develop sense of appreciation to their mothers who epitomize Chinese culture to them. For instances, after Suyuan's death, Jing-Mei starts to play the piano, an act that would have pleased her mother. Also, she replaces her mother at the mah-jong table, and finally, returns to China to fulfill her mother's wish to be reunited with her long lost daughters. While returning to China she feels; "The minute our train leaves the Hong Kong border and enters Shenzhen, China, I feel different... And I think, My mother was right. I am becoming Chinese" (1989). Such realization is the reinvention of new dimension of her cultural identity.

The American born daughters search the support of their Chinese American mothers in order to cope up with problems and crises of their lives. Taking support from her mother, Lena establishes her right in her relationship with her husband. In fact, her mother Ying- Ying instigates courage and strength to fight for her right in her conjugal life with her American husband. Lena fears being inferior to her husband, but does not 
realize he has taken advantage of her both at home and at work, where he is also her boss and earns much more than her. Lena feels frustrated and powerless. Ying-Ying encourages Lena to stop being passive and stand up for her right. Then, she realizes the importance of fight for right and revises her obsession to the Whites. She fights back by refusing to leave the house and wins her share of property in her divorce. Such support of mothers who embody Chinese culture and ancestry help daughters to revise their view about their Chinese lineage and cultural heritages.

In fact, immigrant American identity remains blurred and confusing. To identify with country of their origin becomes unacceptable for the second generation immigrants, when they are brought up and educated in America. Their parents memories of origin seem to be alien to them, and the biological traits of their origin only brings the racists hostile situation to them. Therefore, they do not want to be associated with this country. On their way, to identify with the white American, they realize their skin color, ethnic traits, and family tradition always make them non-american in the white's eyes. The rejection of the white society frustrates them. But at the same time encourages them to explore the immigrants' ethnic identity.

\section{CONCLUSION}

In Tan's narratives, characters oscillate between two cultures because they are not totally free from their shared and common ancestry and history that is 'being' in Hall's concept. At the same time, they are negotiating with their present and reforming themselves, which Hall terms 'becoming'. In fact, both the ' being' and 'becoming' conjointly recreate an immigrant's cultural identity in the new world far away from their native land. Moreover, their cultural interactions produce ambivalence in them, simultaneously attracted and distracted both to their present and past. Such interactions lead immigrant characters in the third space which is doubling and assembling space of being and becoming. This is, in a sense, living in at least two places at once. Such existence constantly negotiates and transforms in a gradual process of identity formation, which inherently remains fluid and ever changing.

\section{REFERENCES}

Bhabha, H. (1994). The location of culture. Routledge.

Chen, X. (2017). Reading mother's tale-reconstructing women's space in Amy Tan and Zhang Jei. Chinese Literature: Essay, Articles, Reviews 111-132. Retrieved 24 Oct.2017 from https://www.jstor. org/stable/495309. 
Chin, F. (1974). (Ed.) An anthology of Asian American writers. Harvard University Press, 1974.

Dunick, L. (1996). M.S. the silencing effect of canonicity: Authorship and the written world in amy tan's novels. MELUS, 31, .3-20. Retrived 12 Oct. 2012 from https://www.uta.edu/faculty/kulesz/Engl\%20 3370/22885461.pdf.

Hall, S. (1994). Cultural identity and diaspora. In Williams and L. Chrisman (Eds.). Colonial discourse and port colonial theory: A reader. Columbia UP.

Lofti, N. T. (2015). Diasporic authenticity assertions: Analysis of Amy Tan's the Bonesetter's daughter." International Journal of Applied Linguistics \& English Literature, (4), (4), 154-160. Retrieved 30 Oct. 2017 from http://www.journals.aiac.org.au/index.php/IJALEL/article/ view/1444.

Lowe, L. (1996). Heterogeneity, hybridity, multiplicity: Asian American difference. Immigrant Acts on Asian American Cultural Politics. 60- 83.

Romangnolo, C. (1994). Narrative beginnings in Amy Tan's The Joy Luck Club: Feminist Study. Studies in the Novel, (19), (2), 99- 124. Retrieved 24 Oct. 2017 from http://www.jstor.org/ stable/29533550.

Xu, B. (2017). Memories and the ethnic self: Reading Amy Tan's The Joy Luck Club." MELUS, (19), 1, 2-18. Retrieved 12 Oct. 2017 from https://www.jstor.org/stable/467784.

$\mathrm{Xu}, \mathrm{W}$. (2009). A womanist production of truth: The use of myths in Amy Tan. In Harold B. (Ed.). Bloom's Modern Critical Views: Amy Tan. 85-94. Infobase publishing.

Yuan, Y. (2017). The semiotics of China narratives in the conexts of Kingston and Tan. Critique, (40), (3), Retrived from 292-303.doi. org/10.1080/00111619909604914.

Zeng, L. (2008). Diasporic self, cultural other: Negotiating ethnicity through transformation in the fictions of Tan and Kingston. Language and Literature, (28), 1-15. Retrieved Sept. 2017 from http://connection. ebscohost.com/c/literary-criticism/15207177/diasporic-selfcultural-other-negotiating-ethnicity-through-transformationfiction-tan-kingston. 